\title{
11. CARBONATE CEMENTS AND FLUID CIRCULATION IN INTRAPLATE DEFORMATION ${ }^{1}$
}

\author{
Jacques Boulègue $^{2}$ and Andre Mariotti ${ }^{3}$
}

\begin{abstract}
The carbonate cements found in Sites 717-719 of ODP Leg 116 correspond to the precipitation of inorganic calcite due to circulation of hot fluid associated with intraplate deformation in the central Indian Ocean. A first burst of hydrothermal activity may have occurred 7.5-9 Ma and a second burst less than $0.5 \mathrm{Ma}$. These fluids were probably derived from the basaltic basement and the immediately overlying sediments.
\end{abstract}

\section{INTRODUCTION}

The fluid chemistry data of Leg 116 suggested that fluid circulation may have been quite important (Shipboard Scientific Party 1989a, b, c). The shipboard observations of the core also showed the possible existence of inorganic precipitation in some of the silt-sand levels. These facts suggested that fluid circulation may have occurred in the past and so might be characterized by study of these carbonate cements. Because, in sedimentary environments, sulfide production often accompanies $\mathrm{CO}_{2}$ production, we have also sampled some sulfides (determined on the basis of smear-slide observations) to differentiate between organic-derived sulfide and that related to fluid circulation.

\section{SAMPLING}

Fifty-four solid samples, $2 \mathrm{~g}$ each, (10 from Site 717, 34 from Site 718, and 10 from Site 719) were selected on the basis of smear-slide descriptions, for studying carbonate deposition and possible sulfide formation related to pore-fluid chemistry. Among these samples, 10 were for study of sulfides and 45 for the study of carbonates. Several of the samples for sulfides have had to be discarded due to oxidation of microspherules of $\mathrm{FeS}_{2}$ during storage. Only five samples were usable for studying the identity and the composition of the sulfides: $116-717 \mathrm{C}-87 \mathrm{X}, \mathrm{CC} ; 116-718 \mathrm{C}-37 \mathrm{X}-1$, 95-96 cm; $116-718 \mathrm{C}-$ $63 \mathrm{X}-5,80-81 \mathrm{~cm} ; 116-718 \mathrm{C}-72 \mathrm{X}-2,106-107 \mathrm{~cm} ; 116-718 \mathrm{C}-$ $90 \mathrm{X}-1,20-21 \mathrm{~cm}$. After X-ray diffraction and electron microscope scanning, few samples revealed enough inorganic carbonates to be worth studying. The samples listed in Table 1 were retained.

Sample $116-717 \mathrm{C}-87 \mathrm{X}, 25-26 \mathrm{~cm}$, is from a $15-\mathrm{cm}$ thick slab of carbonate-cemented sand, which is intersected in the vertical plane by a carbonate vein. This vein was injected after the main cementation of the sand.

\section{ANALYSES}

The samples were analyzed by X-ray diffraction for bulk mineralogical composition, and several of the carbonate samples were also examined by scanning electron microscopy. All samples were prepared as polished smear slides for

\footnotetext{
${ }^{1}$ Cochran, J. R., Stow, D.A.V., et al., 1990. Proc. ODP, Sci. Results, 116: College Station, TX (Ocean Drilling Program).

2 Laboratoire de Géochimie et Métallogénie, CNRS URA 196, UPMC, 4, Place Jussieu 75005 Paris, France.

${ }^{3}$ Laboratoire de Biogéochimie IsotoPique, CNRS URA 196, UPMC, 4, Place Jussieu, 75005 Paris, France.
}

electron microprobe measurements. Sulfide samples were also treated by wet chemistry $\left(\mathrm{HCI}+\mathrm{HNO}_{3}\right)$ for total trace-element determination by atomic absorption spectrometry.

Carbonate samples were further analyzed for carbon and oxygen isotope composition. Results are expressed in $\delta^{13} \mathrm{C}$ and $\delta^{18} \mathrm{O}$ vs. Peedee belemnite (PDB).

\section{RESULTS}

The carbonate in the samples was always calcite. The calcite vein in Sample 116-717C-87X, CC, has a composition:

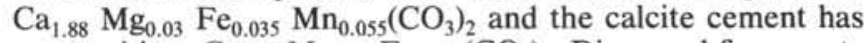
composition: $\mathrm{Ca}_{1.82} \mathrm{Mg}_{0.05} \mathrm{Fe}_{0.11}\left(\mathrm{CO}_{3}\right)_{2}$. Dispersed fine quartz (micrometer size) was intimately mixed with the carbonate crystals. The trace metal compositions of these carbonates are given in Table 2.

Pyrite as well as chalcopyrite, isolated or as a segregation in pyrites, were found in Sample 116-717-87X, CC. The compositions of these minerals are given in Table 3 . The results of the isotopic measurements are given in Table 4 and Figure 1.

\section{Isotopic Composition of Carbonates}

The nannofossil-ooze and the foraminifer-chalk samples show $\delta^{18} \mathrm{O}$ and $\delta^{13} \mathrm{C}$ values corresponding to those generally found in present-day marine sediments. The samples in which inorganic carbonate precipitation is thought to have occurred are characterized by low $\delta^{18} \mathrm{O}:-9 \%$ to $-12 \%$, in a narrow range of $\delta^{13} \mathrm{C}$ values: $-0.6 \%$ to $-2.3 \%$. The isotope composition of the samples corresponding to a mixture of biogenic and inorganic carbonates have an intermediate position between the biogenic and inorganic samples on a $\delta^{13} \mathrm{C}-\delta^{18} \mathrm{O}$ plot. This suggests that the carbonate corresponds to a mixing of two phases with limited dissolution-reprecipitation. The carbonate must have precipitated at an earlier stage as the interstitial water in the vicinity of Cores 116-718-84X to $-718-97 \mathrm{X}$ are presently all undersaturated with respect to calcite, except for Core 116-718-94X.

The carbonates from Sample 116-717C-87X, CC have an isotopic composition very different from the other samples, with a more negative $\delta^{13} \mathrm{C}(-11.9 \%$ to $-13.2 \%$ ). These results show that there have been at least two events leading to the precipitation of inorganic carbonates in the area of Sites 717-719. The events corresponding to the precipitation of carbonate with more negative $\delta^{18} \mathrm{O}$ values must have occurred after the deposition of the youngest carbonate-bearing sediment layer, Section 116-719C-5X-1. According to the lithostratigraphic data, this layer dates at about $0.5 \mathrm{Ma}$. Thus this 
Table 1. Sample reference descriptions and depths.

\begin{tabular}{|c|c|c|c|}
\hline Sample \# & Sample ref. 116- & Description & $\begin{array}{l}\text { Depth } \\
\text { (mbsf) }\end{array}$ \\
\hline 1 & $717 \mathrm{C}-87 \mathrm{X}-\mathrm{CC}, 25-26 \mathrm{~cm}$ & Carbonate cemented sand & 796.5 \\
\hline 2 & $717 \mathrm{C}-87 \mathrm{X}-\mathrm{CC}, 25-26 \mathrm{~cm}$ & Calcite vein intersecting & 796.5 \\
\hline 3 & $718 \mathrm{C}-17 \mathrm{X}-6,24-25 \mathrm{~cm}$ & Nannofossil ooze & 169.04 \\
\hline 4 & $718 \mathrm{C}-25 \mathrm{X}-\mathrm{CC}, 22-23 \mathrm{~cm}$ & $\begin{array}{l}\text { Sand very coarse }+ \text { clay }+ \\
\text { inorganic carbonate }\end{array}$ & 239.31 \\
\hline 5 & $718 C-72 X-4,100-101 \mathrm{~cm}$ & Carbonate ooze (nannofossil) & 689.30 \\
\hline 6 & $718 \mathrm{C}-78 \mathrm{X}-1,10-11 \mathrm{~cm}$ & Carbonate ooze (nannofossil) & 740.90 \\
\hline 7 & $718 \mathrm{C}-78 \mathrm{X}-4,71-72 \mathrm{~cm}$ & $\begin{array}{l}\text { Carbonate ooze (chalk, } \\
\text { nannofossil) }\end{array}$ & 746.01 \\
\hline 8 & $718 \mathrm{C}-86 \mathrm{X}-3,29-30 \mathrm{~cm}$ & $\begin{array}{l}\text { Carbonate ooze (nannofossil } \\
\text { ooze }+ \text { inorganic) }\end{array}$ & 820.09 \\
\hline 9 & $718 \mathrm{C}-93 \mathrm{X}-\mathrm{CC}, 30-31 \mathrm{~cm}$ & Clay-nannofossil ooze & 878.89 \\
\hline 10 & $718 \mathrm{C}-94 \mathrm{X}-1,38-39 \mathrm{~cm}$ & $\begin{array}{l}\text { Clay-foraminifers inorganic } \\
\text { carbonate }\end{array}$ & 887.88 \\
\hline 11 & $718 C-94 X-6,114-115 \mathrm{~cm}$ & Clay-foraminifers & 896.14 \\
\hline 12 & $718 \mathrm{C}-96 \mathrm{X}-1,8-9 \mathrm{~cm}$ & Clay_nannofossils & 906.58 \\
\hline 13 & $719 \mathrm{~A}-5 \mathrm{X}-1,49-50 \mathrm{~cm}$ & $\begin{array}{l}\text { Silt-inorganic } \\
\text { carbonate-few } \\
\text { foraminifers }\end{array}$ & 33.20 \\
\hline 14 & $719 \mathrm{~A}-18 \mathrm{X}-5,124-125 \mathrm{~cm}$ & Clay-foraminifers-micritic & 163.44 \\
\hline 15 & $719 A-40 X-C C, 36-37 \mathrm{~cm}$ & $\begin{array}{l}\text { Calcareous (inorganic) silty } \\
\text { clay }\end{array}$ & 374.70 \\
\hline
\end{tabular}

Table 2. Molal composition (for two $\mathrm{CO}_{3}$ ) trace metals in carbonates in Sample 116717C-87X, CC, obtained by electron microprobe (based on 50 analyses of each).

\begin{tabular}{lcccc}
\hline Sample & $\mathrm{Sr}$ & $\mathrm{Cu}$ & $\mathrm{Zn}$ & $\mathrm{Cd}$ \\
\hline Vein & 0.00041 & 0.001 & 0.0012 & 0.0012 \\
Cement & 0.00045 & 0.0022 & 0.0013 & 0.0008 \\
\hline
\end{tabular}

carbonate precipitation is a relatively recent event (Shipboard Scientific Party, 1989a, b, c).

A temperature range for the precipitation of $\mathrm{CaCO}_{3}$ in samples 4,13 , and 15 can be computed if $\delta^{18} \mathrm{O}$ of the corresponding fluid is known. The calculations of the temperatures can be done according to two different assumptions: (1) the $\delta^{18} \mathrm{O}$ of the water is close to the $\delta^{18} \mathrm{O}$ of nearby pore water (see Table 4); and (2) the ${ }^{18} \mathrm{O}$ of the water is close to $+2 \%$, i.e. that of an hydrothermal water having reacted extensively with basalt. Note that the first assumption is not easy to sustain from the point of view of chemistry, because the interstitial waters at the corresponding levels are all undersaturated with respect to calcite (Shipboard Scientific Party, 1989b, c).

The results of the calculation (Table 5) show that, whichever the assumption, the temperatures reached prior to precipitation are much higher than today's temperatures. The attainment of such high temperatures requires a heat source and feeder channel efficient enough to transport the water with limited heat dispersion. The three levels where carbonates have precipitated are sandy silts that may have acted to channel hot water laterally away from a fault reaching the basement. Locally the sediment depth is about $1.2-1.5 \mathrm{~km}$. With a present day temperature gradient (about $34^{\circ}-38^{\circ} \mathrm{C} / \mathrm{km}$ ), the heat source must have been in the basement rocks. The fact that the temperature was high enough in the basement to obtain a positive shift in $\delta^{18} \mathrm{O}$ by interaction with the basalt agrees with the high temperature calculated for the carbonate cements at Site 718 located 1.8 and $4 \mathrm{~km}$ from possible feeder faults, and for Site 719 located 3.3 and $4.8 \mathrm{~km}$ from possible feeder faults (Shipboard Scientific Party, 1989d).

The carbon source for the deposition of these high-temperature carbonates can be characterized by its $\delta^{13} \mathrm{C}$. At temperatures in the range $70^{\circ}-100^{\circ} \mathrm{C}$, the difference $\Delta$ in $\delta^{13} \mathrm{C}$ between total dissolved carbonate and calcite is $\Delta \delta 13 \mathrm{C}\left(\mathrm{\Sigma CO}_{2}-\mathrm{CaCO}_{3}\right)$ $\approx-2.5 \% \circ( \pm 0.1)$ (Friedman and O'Niel, 1977). Thus the dissolved carbonate source should present $\delta^{13} \mathrm{C}$ in the range $-3.0 \%$ to $-5.0 \%$ (vs. PDB). This may be obtained in the interstitial water either by mixing initial $\Sigma\left(\mathrm{CO}_{2}\right)$ from seawater with $\Sigma\left(\mathrm{CO}_{2}\right)$ derived from diagenesis of organic matter, or by mixing with a $\Sigma\left(\mathrm{CO}_{2}\right)$ source derived from the basaltic crust. The $\delta^{13} \mathrm{C}$ nature of the carbonate cannot help differentiate between these possible sources of dissolved carbonate.

\section{Isotopic Compositions of Carbonate Samples 1 and 2}

We now discuss the second occurrence of inorganic carbonates, i.e., those found in Sample 116-717C-87X, CC (samples 1 and 2). These carbonates have quite low $\delta^{13} \mathrm{C}$ compared with those discussed above. The corresponding temperatures of formation computed vs. the local interstitial water (see Table 4) or an hydrothermal water with $\delta^{18} \mathrm{O}=+2 \%$ (SMOW) are given in Table 6 . These computations are done taking into account the $\mathrm{Mg}$ content of the carbonates (Matsumoto and Matsuhisa, 1986). It appears that the cement as well as the vein may have formed at a lower temperature than those found today, or at a temperature similar to the present temperature if from a hydrothermal component. Several points lead us to prefer the second solution. The sulfide associated with the carbonates, i.e., $\mathrm{CuFe}_{2}-\mathrm{FeS}_{2}$, indicates a high temperature end member for the parent fluid. Also, the chemistry of pore waters from the section below these carbonates have several characteristics of fluids having been in contact with deep-seated sediments or with the ocean basement (Shipboard Scientific Party, 1989a).

The results show that the temperature of formation of sample 2 is slightly higher than for sample 1 . Sample 2 is a vein cross-cutting the indurated layer of sample 1 , and hence deposited subsequently. This signifies that deposition of sample 2 corresponds to either heating of the fluid system or to the tapping of higher temperature fluids that produced enough overpressure to induce vein penetration. The relative time scale of formation of these carbonates vs. the higher temperature ones discussed above cannot be determined on the basis of our results.

The isotopic composition of the total dissolved carbon corresponding to samples 1 and 2 should be in the range 
Table 3. Composition of sulfides (in wt \%o) of Sample 116-717C-87X, CC obtained by electron microprobe (based on 50 analyses of each mineral type).

\begin{tabular}{lccccccc}
\hline Mineral & $\mathrm{As}$ & $\mathrm{Cu}$ & $\mathrm{Mn}$ & $\mathrm{Pb}$ & $\mathrm{Ni}$ & $\mathrm{Co}$ & Others \\
\hline $\mathrm{FeS}_{2}$ & 0.09 & $0.1-8$ & $0-0.09$ & & $0-0.5$ & & $\begin{array}{c}\text { Traces of } \mathrm{Zn}, \\
\mathrm{Sb}, \mathrm{Cd}, \mathrm{Ag}\end{array}$ \\
$\mathrm{CuFeS}_{2}$ & 0.745 & & & 0.59 & $0-1.4$ & $0-0.2$ & \begin{tabular}{c} 
Traces of $\mathrm{Sb}, \mathrm{Cd}$ \\
\hline
\end{tabular}
\end{tabular}

Table 4. Carbon and oxygen isotopic composition given in $\delta^{13} \mathrm{C}(\%)$ and $\delta^{18} \mathrm{O}(\%)$ vs. PDB. Also given: $\delta^{18} \mathrm{O}$ (\%o vs. SMOW) of closest pore-water sample.

\begin{tabular}{|c|c|c|c|}
\hline Sample \# & $\delta^{13} \mathrm{C}$ & $\delta^{18} \mathrm{O}$ & $\begin{array}{c}\text { Pore-water sample \# } \\
\text { and } \delta^{18} \mathrm{O} \text { of pore water }(\%)\end{array}$ \\
\hline 1 & -13.2 & -1.3 & $87 X-1 ;-1.43$ \\
\hline 2 & -11.9 & -2.0 & $91 X-3 ;-1.21$ \\
\hline 3 & -3.7 & -0.2 & $3 \mathrm{X}-2 ;-0.3$ \\
\hline 4 & -2.3 & -11.3 & $25 \mathrm{X}-1 ;-1.01$ \\
\hline 5 & -4.7 & -1.6 & \\
\hline 6 & -5.2 & -0.2 & $74 X-1 ;-1.60$ \\
\hline 7 & -0.5 & -0.9 & \\
\hline 8 & -2.9 & -3.3 & $84 X-1 ;-1.63$ \\
\hline 9 & -3.4 & -1.2 & \\
\hline 10 & -0.1 & -2.3 & $94 X-4 ;-1.40$ \\
\hline 11 & 0.0 & -1.5 & \\
\hline 12 & -3.7 & -1.0 & $97 X-1 ;-1.72$ \\
\hline 13 & -0.6 & -9.4 & $7 X-1 ;-0.04$ \\
\hline 14 & +0.5 & -0.3 & $20 X-4 ;-0.68$ \\
\hline 15 & -1.5 & -11.6 & $35 X-2 ;-1.47$ \\
\hline
\end{tabular}

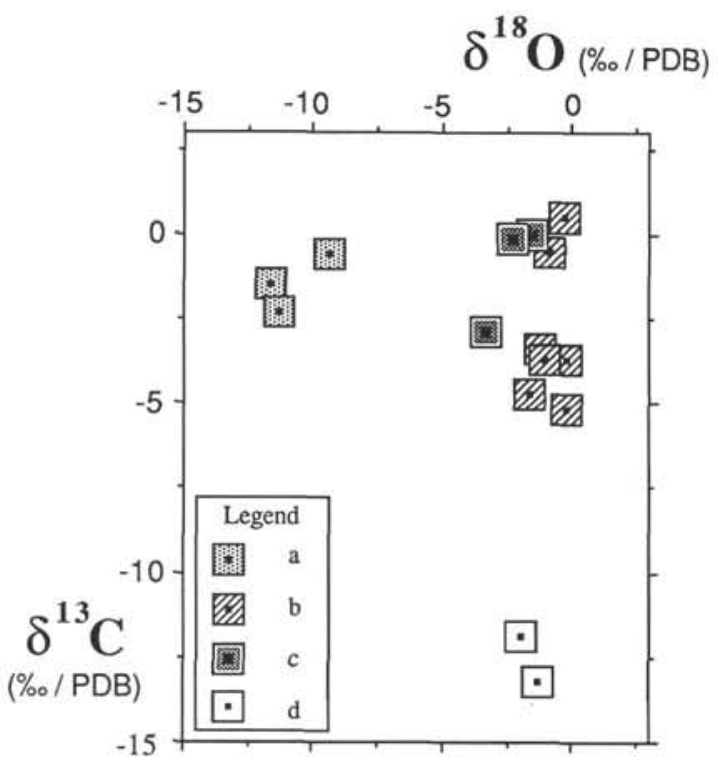

Figure 1. $\delta^{18} \mathrm{O}-\delta^{13} \mathrm{C}$ data for the carbonate cements of Leg 116. The numbers labeling the data points correspond to those of Table 4. Legend: (a) inorganic carbonates; (b) foraminifer and nannofossil ooze; (c) mixture of organic and inorganic carbonates; (d) Sample 116-717-87X, CC.

$-12.5 \%$ to $-15.2 \%$. This may be obtained either from production in the methane-producing zone or in the thermocatalytic zone. Because, at the depths we are dealing with, neither $\mathrm{CH}_{4}$ nor $\mathrm{CO}_{2}$ are extensively produced by fermentation ( $\mathrm{SO}_{4}^{2-}$ is still present), this points toward a deeper origin for the $\Sigma\left(\mathrm{CO}_{2}\right)$-bearing fluids that have deposited the cement and the vein.

\section{Trace Elements in Carbonate Samples 1 and 2}

The trace elements in samples 1 and 2 can be utilized to check the consistency of the temperatures of formation with known partition coefficients of $\mathrm{Mg}, \mathrm{Sr}$, and $\mathrm{Mn}$. The partition coefficient of an element $\mathrm{M}$, forming $\mathrm{MCO}_{3}$, for calcite can be written $\left.\mathrm{DM} / \mathrm{Ca}=\left(\mathrm{XMCO}_{3} / \mathrm{XCaCO}_{3}\right) \mathrm{mCa}^{2+} / \mathrm{mM}^{2+}\right)$, where $\mathrm{X}$ corresponds to the molar fraction in the solid and $\mathrm{m}$ to the molality of the ions. We consider here only $\mathrm{Ca}, \mathrm{Mg}, \mathrm{Mn}$, and $\mathrm{Sr}$, which have complex formation close enough that we can neglect activity coefficient correction (Sverjensky, 1984), and we consider ideal solution behavior in a solid. We can then compare the $\mathrm{mM}^{2+}$ $\mathrm{mCa}^{2+}$ values for the pore waters at the intersection of the carbonate with that calculated from $\mathrm{XMCO}_{3} / \mathrm{XCaCO}_{3}$ data for the solid. The results of these calculations are given in Table 7. In these computations the following partition coefficients have been considered: $\mathrm{DMg} / \mathrm{Ca}=2 \times 10^{-2}(1) ; 5 \times 10^{-2}(2) ; \mathrm{DSr} / \mathrm{Ca}$ $=0.15(1) ; 5 \times 10^{-2}(2) ; \mathrm{DMn} / \mathrm{Ca}=10$ for the $15^{\circ}-35^{\circ} \mathrm{C}$ scale. One can see that the calculated data are in fairly good agreement with the measurements for $\mathrm{Mn}$ and $\mathrm{Mg}$. No agreement is reached in the case of $\mathrm{Sr}$.

These results show that the fluid from which these carbonates have precipitated is probably not very different from the presentday interstitial water as far as $\mathrm{Ca}^{2+}, \mathrm{Mg}^{2+}$ are concerned, although they are different from the interstitial waters of samples 87 and 91 because these waters are oversaturated with respect to low Mg-calcite (Shipboard Scientific Party, 1989a).

In the case of $\mathrm{Sr}$, one can only say that there is much more $\mathrm{Sr}$ in the interstitial waters than is expected from the solid composition. This may reflect the fact that $\mathrm{Sr}$ is controlled by the dissolution of biogenic carbonates, in which $\mathrm{Sr}$ is more enriched than in organic carbonates. This is in agreement with the considerations of trace metals in the pore waters of ODP Leg 116 samples (Boulègue et al., this volume).

Thus it appears that the carbonate found at $796.5 \mathrm{mbsf}$ in a hard slab of carbonate-cemented sand is most likely formed by 
Table 5. Formation temperatures of carbonates computed for two different water isotopic compositions. (1) vs. interstitial water (i.w.), (2) vs. hydrothermal water (h.w.). Also given: depth of layer and present-day temperature computed from temperature gradient $\left(37^{\circ} \mathrm{C} / \mathrm{km}\right)$.

\begin{tabular}{lcccr}
\hline \multicolumn{1}{c}{ Sample 116- } & $\mathrm{T}\left({ }^{\circ} \mathrm{C}\right)$ vs i.w. & $\mathrm{T}\left({ }^{\circ} \mathrm{C}^{\prime}\right)$ vs h.w. & $\mathrm{T}\left({ }^{\circ} \mathrm{C}\right)$ of layer & $\begin{array}{r}\text { Depth } \\
(\mathrm{mbsf})\end{array}$ \\
\hline 718C-25X, CC, 22-23 & 77 & 97 & 10.5 & 239.31 \\
719A-5X-1, 49-50 & 69 & 87 & 3 & 33.20 \\
$719 \mathrm{~A}-40 \mathrm{X}, \mathrm{CC}$ & 74 & 98 & 16 & 374.70 \\
\hline
\end{tabular}

Table 6. Temperature of formation of carbonates computed in two different water isotopic compositions. (1): vs. interstitial water (i.w.), (2) vs. hydrothermal water (h.w.). Depth of layer and present-day temperature computed from temperature gradient $\left(37^{\circ} \mathrm{C} / \mathrm{km}\right)$.

\begin{tabular}{ccccc}
\hline Sample 116- & $\mathrm{T}\left({ }^{\circ} \mathrm{C}\right)$ vs i.w. & $\mathrm{T}\left({ }^{\circ} \mathrm{C}^{\prime}\right)$ vs h.w. & $\mathrm{T}\left({ }^{\circ} \mathrm{C}\right)$ of layer & $\begin{array}{r}\text { Depth } \\
\text { (mbsf) }\end{array}$ \\
\hline $717 \mathrm{C}-87 \mathrm{X}, \mathrm{CC}$ cement $(\# 1)$ & 16 & 32 & 32. & 796.5 \\
$717 \mathrm{C}-87 \mathrm{X}, \mathrm{CC}$ vein $(\# 2)$ & 20 & 35 & 32 & \\
\hline
\end{tabular}

Table 7. Ratios of the molality of ion $\mathrm{M}^{2+}$ to molality of $\mathrm{Ca}^{2+}$ in interstitial water $\left(\mathrm{mM}^{2+} / \mathrm{mCa}^{2+}\right)$ i.w., compared with the same ratio calculated from solid composition data for samples 1 and $2\left(\mathrm{mM}^{2+} / \mathrm{mCa}^{2+}\right)$ C. Sample $1=$ cement, sample $2=$ vein.

\begin{tabular}{lcccccc}
\hline \multicolumn{1}{c}{ Element (M) } & \multicolumn{2}{c}{$\mathrm{Mg}$} & \multicolumn{2}{c}{$\mathrm{Sr}$} & \multicolumn{2}{c}{$\mathrm{Mn}$} \\
\hline Solid sample (\#) & 1 & 2 & 1 & 2 & 1 & 2 \\
\hline$\left(\mathrm{M}^{2+} / \mathrm{Ca}^{2+}\right) \mathrm{C}(1)$ & 1.4 & 0.8 & $1.7 \times 10^{3}$ & $1.5 \times 10^{-3}$ & $5.5 \times 10^{-4}$ & $3 \times 10^{-3}$ \\
$\left(\mathrm{M}^{2+} / \mathrm{Ca}^{2+}\right) \mathrm{C}(2)$ & 0.55 & 0.3 & $5 \times 10^{-3}$ & $4.5 \times 10^{-3}$ & & $5.2 \times 10^{-4}$ \\
$\left(\mathrm{M}^{2+} / \mathrm{Ca}^{2+}\right)$ i.w. \#87 & 1.11 & & $1.2 \times 10^{-2}$ & $1.1 \times 10^{-3}$ \\
$\left(\mathrm{M}^{2+} / \mathrm{Ca}^{2+}\right)$ i.w. \#91 & 0.83 & & $1 \times 10^{-2}$ & \\
\hline
\end{tabular}

permeation of hot water through the sand layer and efficient cementation of the sand with low-Mg calcite. The deposition of the sand layer occurred at about $9 \mathrm{Ma}$ (Shipboard Scientific Party, 1989a). The movement on the fault block beneath Site 718 began about $7.5-8 \mathrm{Ma}$. It is possible that a hot fluid penetrated the sand layer, which at that time would have been only about $100-150 \mathrm{mbsf}$, and precipitated the carbonate cement. This would have been quite similar to what is observed presently in the top $150 \mathrm{mbsf}$ of hole 718 . The sealing of the system by the cement could have induced overpressure, and continuation of fluid circulation then led to fracturing and deposition of vein calcite (sample 2).

\section{Sulfide Chemistry}

The sulfides found in other sedimentary layers and associated with biological structures are exclusively pyrite, having a very different composition from the pyrite of samples 1 and 2 . This pyrite, derived from sulfate reduction of biogenic materials, has a high arsenic content: $0.20 \%$ (Sample 116-718C$37 \mathrm{X}-1$, 95-96 cm); 0.67\%。 (Sample 116-718C-63X-5, 80-81 $\mathrm{cm}$ ); $0.80 \%$ (Sample 116-718C-72X-2, 106-107 cm); $0.57 \%$ o (Sample 116-718C-90X-1, 20-21 cm), whereas in samples 1 and 2 it is less than $0.1 \%$.

The trace metal content of biologically-derived pyrite is low and varies from one measurement point to another under the electron microprobe. The trace metal content of $\mathrm{FeS}_{2}$ and $\mathrm{CuFeS}_{2}$ in samples 1 and 2 is higher (see Table 3). Thus the biological pyrite and the sulfides associated with the carbonate deposits of Sample 116-717C-87X, CC, have a quite different composition.

The association of $\mathrm{FeS}_{2}$ and $\mathrm{CuFeS}_{2}$ in Sample 116-717C$87 \mathrm{X}, \mathrm{CC}$, is also another point in favor of the high-temperature origin of the fluid, as it may have been derived from the leaching of the upper layer of the basaltic crust.

\section{CONCLUSION}

The study of carbonate and sulfide formation in the coarsegrained sediment layers of the Bengal Fan, located in an area of intraplate deformation, supports the existence of strong hydrothermal activity concomitant with the deformation.

We have recognized carbonate cementation of a sand layer followed by carbonate vein formation through this same cemented sand. The temperature of formation of the vein calcite $\left(20^{\circ}\right.$ or $\left.35^{\circ} \mathrm{C}\right)$ is only slightly higher than that of the cementation $\left(16^{\circ}\right.$ or $\left.32^{\circ} \mathrm{C}\right)$. Sulfides $\mathrm{FeS}_{2}$ and $\mathrm{FeCuS}_{2}$ were deposited at approximately the same time. This suggests that the fluid was most probably a relatively high-temperature fluid that may have upwelled along a fault zone and spread laterally through the permeable sand layer. This event may have occurred soon after the movement on the fault block began, i.e., about 7.5-8 Ma. The sand layer was then buried at a depth of about $100-150 \mathrm{mbsf}$, which would have aided the flow of the hot fluid through it and hence caused the cementation. Continuation of the fluid circulation may have induced overpressure, fracturing, and carbonate vein filling. This hot fluid advection was probably similar to that recognized today in the upper $150 \mathrm{mbsf}$ at Site 718 , where hot fluid ascending along a fault permeates laterally through shallow sandy layers (Shipboard Scientific Party, 1989b).

A second hydrothermal event has been recognized, which has precipitated carbonate in permeable sand-silt layers at still more elevated temperatures of about $70^{\circ}-100^{\circ} \mathrm{C}$. This carbonate is found in sediment layers that are only $0.5 \mathrm{Ma}$, indicating a relatively recent event. It presumably has involved a large amount of fluid, because it is identified in several different 
sediment layers. The hot upwelling fluids responsible for the deposition of this second set of inorganic carbonates were most likely derived from the sediment just above the basement as well as from the basaltic basement.

Today, as shown by the pore-water data, hydrothermal activity is still going on. The plumbing of the system is such that faults act probably as discharge conduits, water spreading out laterally through permeable silt and sand layers. In a more buoyant regime, hydrothermal activity at the seafloor is probably active. The faults may also act as recharge zones because the results of water chemistry indicate recent mixing of seawater with pore-water in deep sand layers (Shipboard Scientific Party, 1989a).

These results show the importance of fluids in intraplate deformation areas. Their role in the mechanics of the deformation still remain to be understood. Another question is the relation between the mechanical energy involved in deformation and the thermal energy released by upwelling of hot fluids.

\section{REFERENCES}

Friedman, I., and O'Niel, J., 1977. Compilation of stable isotope fractionation factors of geochemical interest. Geol. Surv. Prof. Pap. U.S., 440-KK.
Matsumoto, R., and Matsuhisa, Y., 1986. Chemistry, carbon and oxygen isotope ratios, and origin of deep-sea carbonates at sites 438, 439 and 584: inner slope Japan Trench. Init. Repts. DSDP, 87: Washington (U.S. Govt Printing Office), 669-678.

Shipboard Scientific Party, 1989a. Site 717: Bengal Fan. In Cochran, J. R., Stow, D.A.V., et al., Proc. ODP, Init. Repts., 116: College Station, TX (Ocean Drilling Program), 45-90.

Shipboard Scientific Party, 1989b. Site 718: Bengal Fan. In Cochran, J. R., Stow, D.A.V., et al., Proc. ODP, Init. Repts., 116: College Station, TX (Ocean Drilling Program), 91-154.

Shipboard Scientific Party, 1989c. Site 719: Bengal Fan. In Cochran, J. R., Stow, D.A.V., et al., Proc. ODP, Init. Repts., 116: College Station, TX (Ocean Drilling Program), 155-196.

Shipboard Scientific Party, 1989d. ODP Leg 116 Site Survey. In Cochran, J. R., Stow, D.A.V., et al., Proc. ODP, Init. Repts., 116: College Station, TX (Ocean Drilling Program), 197-212.

Sverjensky, D. A., 1984. Prediction of Gibbs free energies of equilibrium distribution of trace elements between carbonates and aqueous solutions. Geochim. Cosmochim. Acta, 48:1127-1134.

Date of initial receipt: 5 February 1990

Date of acceptance: 5 February 1990

Ms 116B-134 